\title{
Diamond Jenness
}

\section{and 'useful anthropology' in Canada $1930-1950$}

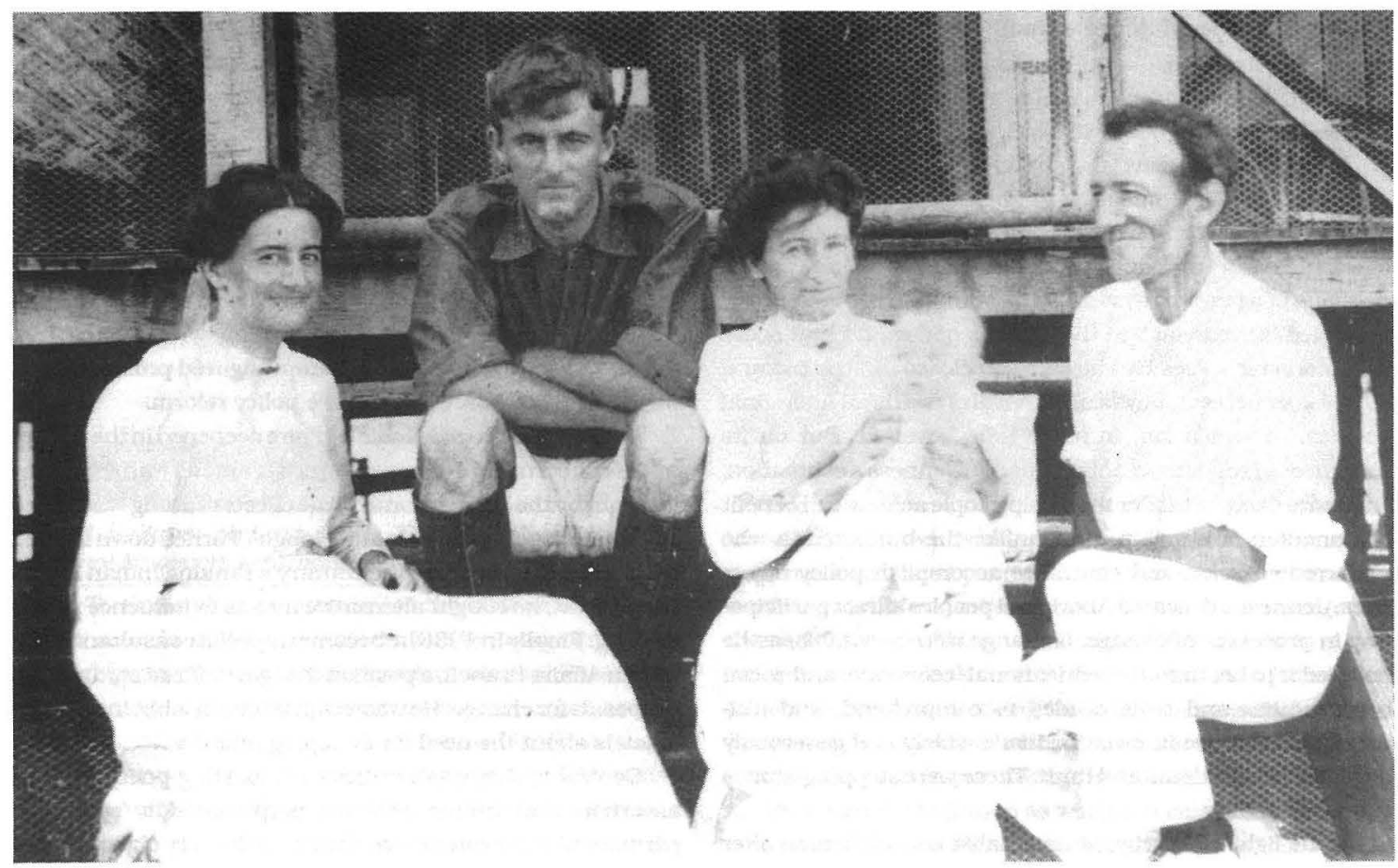

Diamond Jenness (1886-1969) was a New Zealand Anthropologist who conducted research in Canada among Indians and Inuit. Towards the end of his career he devoted himself to research with policy implications. The Anthropology Department at Victoria University of Wellington is named after Jenness.

\section{BARNETT RICHLING}

In June 1969 a revolution began in Canadian Aboriginal affairs. The recently-elected Liberals under P.E. Trudeau set things in motion by releasing a statement on federal Indian policy, the aptly-named 'White Paper'. They proposed an allnew course for relations with Indians, a course consistent with the high ideals of the Prime Minister's Just Society and aimed at righting the cumulative wrongs of the past. Declaring that equality alone was the solution to the nation's 'Indian Problem', the Government proposed makin g Indians ordinary citizens by doing away with the complex legal and administrative apparatus that underlay their historic ward-
From left: Grace Jenness, New Zealand-born anthropologist Diamond Jenness, May Ballantyne holding baby Allan, and Andrew Ballantyne on Goodenough Island, Canada, 1911. [Ballantyne Family]

ship status, and contributed to their sub-standard living conditions, economic marginality, low educational achievement, and welfare dependency.

Indians did not herald the White Paper as a blueprint for liberation. Instead, they condemned it as the old national policy of assimilation wrapped in a thin cloak of egalitarian rhetoric. They argued that the policy repudiated the special Aboriginal and treaty rights of Canada's First Nations, rights they believed essential to social and cultural survival and to their proper status as 'citizens plus'. ${ }^{1}$ Far from a cure-all for a persistent social problem, the White Paper actually energized widespread protest among Aboriginal peoples, spawning a new era of ethnopolitics aimed at the constitutional entrenchment of Aboriginal rights. Government withdrawal of its policy was an early victory, but the revolution continues. 
When NewZealand-born anthropologist DiamondJenness died on 29 November 1969, this revolution was barely five months old. Though illness slowed him in his last years, both mind and wit remained sharp, as did his career-long interest in the past, present, and future of Canadian Aboriginal peoples. 'I have thrown away my pen', he explained to fellow New Zealander Harry Hawthorn, 'having done more than enough mischief in my lifetime.... ${ }^{2}$ Yet he doubtlessly followed reaction to the 'White Paper' in the press. Though nowhere recorded, his views would be of great value to us now since his ideas about Canadian Native administration anticipated by 30 years several premises later embodied in the Government's 1969 initiative.

Drawing on extensive, first-hand knowledge of the Dominion's Indians and Inuit as a National Museum of Canada ethnologist between 1913 and 1947, Jenness witnessed the effects of state administration on them and had strong opinions of where the system was leading. He pessimistically predicted 60 years ago in the Indians of Canada that social and economic forces had already foreclosed on the cultural (and, for some, even physical) survival of nearly all Aboriginal peoples. ${ }^{3}$ Assimilation, in some form, awaited. But on its present course government practice, in Jenness's estimation, was more likely to hinder than help people achieve full benefit of Canadian citizenship. And unlike the bureaucrats who preferred coercion and control to accomplish policy objectives, Jenness advocated Aboriginal peoples' direct participation in processes of change. If change were inevitable, as he believed it to be, than the educational, economic, and social opportunities and tools needed to comprehend, and ultimately to embrace it, must be made widely and generously available to all Indians and Inuit. These were stepping-stones to social equality.

In the light of Aboriginal nationalist consciousness after 1969, some critics have understandably branded Jenness's ideas reactionary, racist, and anti-Native. From a 'presentist' perspective much of his work clearly warrants the taint of oldline assimilationism for advocating termination of special status and 'liquidation' of reserve lands. Yet from the early thirties when he began to delve into 'useful anthropology', Hawthorn's euphemism for research with policy implications, ${ }^{4}$ Jenness was less an apologist for government than a staunch critic of it, putting forward proposals on policy and administrative reform whose purpose was to make Aboriginal peoples full participants in modern Canadian life.

The political and philosophical roots of Jenness's interest in policy issues and of his thought on solutions to the 'Indian Problem', run in many directions. To begin, his New Zealand upbringing disposed him toward the values of humanitarianism, social equality, and Victorian respectability. Born into a middle class Methodist family in Wellington in 1886, his parents were Rechabites and an older sister, May, served with the Methodist Overseas Mission in British New Guinea. Less given to religious than secular-pragmatic views, he equated useful work with human dignity and advancement. This was borne out in early field experiences in the D'Entrecasteaux Islands (1911-12) and the Alaskan and Canadian Arctic (1913-16), both settings where the result of clashing 'primitive' and 'civilized' worlds would surely be determined by the extent to which the colonisers afforded the colonised equitable and practicable means to partake in the fruits of 'progress'. These decidedly liberal ideas were later reflected in his only published theoretical statement on cultural evolution and the causes of 'backwardness' amongAboriginal NorthAmericans, published in 1937 under the title The Indian Background of Canadian History'. He argued here that culture contacts, not the determinism of biological race or temperament, are "the most potent forces in driving man [sic] upward from savagery to civilization....$^{5}$ Jenness often cited the Maori as a shining illustration of this viewpoint, arguing that an integrative approach to race relations in New Zealand enabled them to stand as citizens 'on an equal footing with whites'. ${ }^{6}$ As discussed shortly, the Maori example figured prominently in his thinking on Canadian Native policy reform.

Jenness's interest in Indian affairs deepened in the thirties out of concern for the worsening crisis among Native peoples wrought by the Depression and the effects of a long-outmoded government policy of 'Bible and Plough'. Turned down in 1932 to succeed D.C. Scott as the country's ranking Indian Affairs bureaucrat, he sought alternative means to influence policymaking. Finally in 1936 he became a special consultant to the Indian Affairs Branch, a position that gave official status to his proposals for change. Hewasted little time in lobbying Branch officials about the need for sweeping reforms.

Central to Jenness's criticism of existing policy was the assertion that Indian reserves perpetuated a 'system of permanent segregation' that thwarted the very objective they were designed to achieve: the gradual integration of Indians into the 'larger life of civilization'. In effect, the reserves robbed Indians of their morale, health, and sense of well-being, making them a 'dejected, prison-like population' and the objects of Euro-Canadian prejudice. ${ }^{7}$ In later years he used even stronger language, likening Indian administration to apartheid, the legalities of wardship status its colour bar, reserves its 'bantustans'. ${ }^{8}$ In a series of official memoranda written in the thirties and again in the 'forties during testimony before a Senate-Commons Committee investigating the Indian Act, Jenness steadfastly advocated the urgent need for measures to insure Indians equal opportunities in education and economic life. He reasoned that such steps would restore their self-esteem and sense of purpose, and assist them in entering the mainstream as full citizens. Unsympathetic to Indian calls for unconditional self-determination, Jenness asserted that de facto self-determination would follow only where institutional impediments to social mobility were dismantled and alternatives to legislated dependency put in 


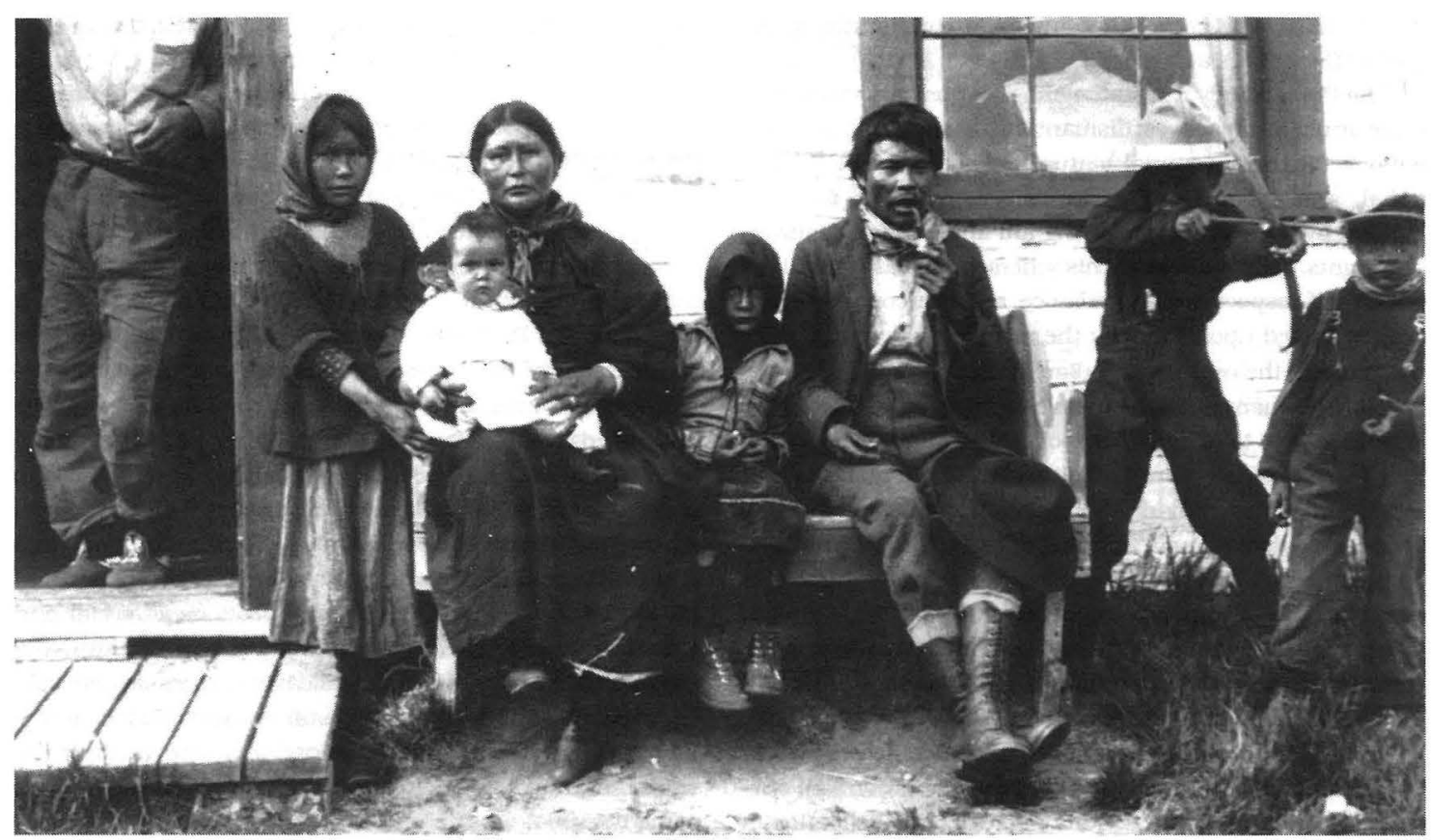

Sekani Indians: McLeod Lake, British Columbia, 1924. [National Museums of Canada]

place. To this end he recommended the closure of separate Indian schools and their replacement by integrated ones, support for promising students to obtain advanced education and training, money for local economic development and improvement of living conditions, and so on. Finally, he urged constructive use of enfranchisement provisions in the Indian Act to encourage entire communities to become self-reliant and to jump-start the process of integration. Raising the spectre of enfranchisement, however tempered by progressive educational and economic reforms, was destined to lead Jenness into murky waters. Then, as now, Native peoples saw the process as anathema to the special rights arising from their status as First Nations.

In the early forties Jenness began looking at Canadian Native administration in comparative terms, making particular reference to the record of Maori affairs. Though he had last visited New Zealand on a brief wedding trip in 1919, he kept abreast of current developments there through correspondence with government officials, including Walter Nash, an old acquaintance. Youthful impressions of Maori-Pakeha relations now figured prominently in his thinking, favourable impressions of friendships with Maori schoolmates and of everyday experiences with neighbours in Wellington and the Hutt Valley. In his mind Canada could do no better than to emulate the New Zealand model of race relations. And in 1947 he testified to that effect before the joint Senate-House Committee, unequivocally stating that New Zealand had 'no

Maori problem' because they held full rights of citizenship and were not a colonised people. Citing the absence of reserves, wardship status and other forms of institutional segregation, the participation of Maori in national affairs, including government, and the lack of racial discrimination in private and public life, he drew nothing but the most unsatisfactory of comparisons between the New Zealand and Canadian experiences. Yet even in portraying his homeland's accomplishments in racial integration as worthy of emulation, assimilation, not integration alone, remained its national goal. Asked by a committee member whether Maori 'are being rapidly absorbed into the general stream of life, ... [so that] in a reasonably short space of time there will be no such thing as a Maori', Jenness simply replied: 'Exactly'. ${ }^{9}$

The centrepiece of Jenness's testimony to the Committee was his oddly titled 'Plan for Liquidating the Indian Problem Within 25 Years', first drafted in 1943. He prefaced its presentation with comments on the consequences, rather than the causes, of that Problem. Returning to the theme of segregation first raised a decade earlier, he likened the situation of Canadian Aboriginal peoples to that of the masses of European victims of Nazism - internees in concentration camps and camps for displaced persons, slave labourers - all of whom endured isolation from 'world currents ... from the life and society all around them', developing debilitating psychological dependencies on their warders and warped mentalities' in the process. Canada's reserve system, he argued, has had a similar effect on Indians, fostering pervasive dependency on the state, undermining their will to escape 
their 'confinement camps' and making them pariahs in the eyes of Canadians at large. ${ }^{10}$

The Plan, largely a restatement of earlier proposals, had three principal objectives: dismantling the institutional foundations of Indian special status; providing social, educational, and economic opportunities comparable to those enjoyed by non-Natives; insuring full and equitable citizenship rights. Jenness believed his scheme would assist Indians regain self-respect and self-reliance and overcome the irrelevance foisted upon them by the reserve system and other trappings of the outmoded Indian Affairs system.

The testimony's most tangible result was to encourage government to take a further look at the Maori case. When they learned of his plans to holiday in New Zealand in late 1947, therefore, Indian Affairs officials quickly enlisted Jenness's cooperation in carrying out a fact-finding mission on their behalf. This was to be his first 'fieldwork' devoted to administrative and policy issues. How ironic that it should take place in New Zealand; after all, he had been calling on the government to initiate this type of study among Canadian Indians since the thirties, to no avail.

More on the order of a brief survey than detailed fieldwork, the work entailed investigation of Maori education and current social and economic conditions. Reaching Wellington in the early winter of 1948 , Jenness had occasion to meet with a number of high government officials, including Prime Minister Peter Fraser who, at the time, held the Native Affairs portfolio, and then conducted a tour of North Island schools. A formal report of his findings, submitted to Indian Affairs later that year, was widely circulated among personnel involved with Native education and welfare. The most favourable comment arising from it was reserved for the high standards and degree of integration already achieved in Maori education. This was an objective Canada would soon attempt to reach by replacing residential schools with federally-run local day schools and by revamping the curriculum to comply with national standards.

Positive mention of the MaoriLand Courts system was also made. No special mechanism to resolve land disputes would be in place in Canada until 1974 when an Office of Native Claims was set up in the Department of Indian Affairs.

Overall, official enthusiasm for the New Zealand experience was tempered by a less-than-favourable assessment of Maori ' progress' in society at large. Referring to one of Jenness's observations, an internal Indian Affairs memorandum explained while there is legal equality, there is still considerable antipathy to Maoris shown by Europeans. This has made it difficult for many Maoris to obtain positions in some of the cities and towns other than as domestics or casual labourers. Racial discrimination, though not officially countenanced, is still practised, but there appears to be evidence that barriers are being broken down. ${ }^{11}$ This was a far cry from the high marks Jenness gave to Maori-Pakeha relations only a few years before: no problem exists, heasserted, because the two peoples are on 'equal footing' as citizens.

In the end, little of a practical nature came of Jenness's proposals on policy reform in the early post-war period. Seemingly unwilling to relinquish its old-style control despite the rhetoric of 'equal citizenship' that permeated the pages of the Special Committee's final report to Parliament, what few changes the government did make over the next decade were mainly symbolic: the transfer of Indian Affairs in 1949 to a newly-created Department of Citizenship and Immigration, replacement of mission-run residential schools with staterun (but not integrated) day schools, entitlement to statesupported social welfare benefits including pensions, unemployment insurance, child allowances, and universal health care. Above all else, the next twenty years witnessed enormous growth in the size of the Native Affairs bureaucracy and in public expenditures on its various programmes. In spite of all of this, on the most pressing questions of social and economic development and equitable access to the mainstream, little had changed. And measures to implement selfdetermination, of course, were still beyond official countenance. Only ten years after the Joint Committee concluded its work the government convened another to look into the very same issues. A version of this paper was read at the Stout Centre on 21 August, 1991. More thorough treatment of his work on Canadian Native policy is to appear in my biography of Jenness, now in progress.

\section{Footnotes}

1. Harry Hawthorn. 1966. A Survey of the Contemporary Indians of Canada: Economic, Political, Educational Needs and Policies. Vol.1. Ottawa: Queen's Printer, p.3.

2. Jenness to Hawthorn, 17.1.1969: University of B.C. Archives.

3. Bulletin 65, Anthropological Series 15. Ottawa: National Museum of Canada, p.264.

4. Sally Weaver. 1976. The Role of Social Science in Formulating Canadian Indian Policy: A Preliminary History of the HawthornTremblay Report. In J. Freedman, Ed. Proceedings No.3 Canadian Ethnology Society. Hamilton: McMaster University, p.86.

5. Bulletin 86, Anthropological Series 21. Ottawa: National Museum of Canada, p. 16.

6. Canada. 1947. Special Joint Committee of the Senate and the House of Commons Appointed to Continue and Complete the Examination and Consideration of the Indian Act. Minutes and Proceedings of Evidence No.7. Ottawa: King's Printer, p.309.

7. Jenness to Charles Camsell, 25.8.36: National Museum of Canada.

8. Diamond Jenness. 1964. Eskimo Administration: II Canada. Montreal: Arctic Institute of North America, pp.93-4.

9. Canada. Special Joint Committee, p.314.

10. Ibid. pp.307-09.

11. D. MacKay to Deputy Minister, 20.11.1950: National Archives of Canada.

Barnett Richling teaches anthropology at Mount St Vincent University, Nova Scotia. 